$12-2016$

\title{
Book Review: Just Remembering: Rhetorics of Genocide Remembrance and Sociopolitical Judgment
}

Jeffrey Blustein

CUNY City College

Follow this and additional works at: https://digitalcommons.usf.edu/gsp

\section{Recommended Citation}

Blustein, Jeffrey (2016) "Book Review: Just Remembering: Rhetorics of Genocide Remembrance and Sociopolitical Judgment," Genocide Studies and Prevention: An International Journal: Vol. 10: Iss. 3:

92-94.

DOI:

http://doi.org/10.5038/1911-9933.10.3.1431

Available at: https://digitalcommons.usf.edu/gsp/vol10/iss3/10

This Book Review is brought to you for free and open access by the Open Access Journals at Digital Commons @ University of South Florida. It has been accepted for inclusion in Genocide Studies and Prevention: An International Journal by an authorized editor of Digital Commons @ University of South Florida. For more information, please contact digitalcommons@usf.edu. 
Jeffrey Blustein

CUNY City College

New York, NY, USA

Just Remembering: Rhetorics of Genocide Remembrance and Sociopolitcal Judgment

Michael Warren Tumolo

Madison, N.J., Fairleigh Dickinson University Press, 2015

124 Pages; Price: $\$ 60.00$ Hardback

Reviewed by Jeffrey Blustein

City College and Graduate Center, City University of New York

The main purpose of this short monograph by Michael Warren Tumolo is to "analyze[s] the rhetoric of a set of extant public memorial texts." ${ }^{1}$ With this as its focus, it is somewhat surprising that the author nowhere even mentions Aristotle, whose classic work Rhetoric has had an enormous influence on the development of the art of rhetoric from ancient times to the present. According to Aristotle, the rhetorician is someone who is always able to see what is possibly persuasive in every given case, ${ }^{2}$ and he presents a general theory of the techniques of persuasion to assist the rhetorician in this, a theory that brings to bear a number of concepts and arguments from his writings in logic, ethics, and psychology. Aristotle's work would have been one way to provide a theoretical framework for the discussion of rhetoric in Tumolo's book, but the book is notably thin on theory. For his authority on rhetoric, he relies chiefly on a single article by John Poulakos, "Towards a Sophistic Definition of Rhetoric." 3 Following Poulakos, Tumolo defines rhetoric as consisting of three aspects: "kairos (opportune moment), propriety, and possibility." ${ }^{4}$ An important question in evaluating this monograph is whether, first, these terms are sufficiently clear to do analytic work and second, this definition is put to good use by helping the reader better understand the persuasive intent and effect of a number of public memorial discourses. Put another way, what is the explanatory gain from viewing the various cases Tumolo discusses (all relating to genocide) through the lens of rhetoric? As I will suggest, I am not persuaded that we gain much.

The monograph is divided into six chapters. Chapter 1 introduces Pulakos's definition, which is referenced again in chapters 5 and 6 . Given the centrality of the notion of rhetoric to the aims of this book, and given that this is an introductory chapter that sets the stage for the ones to follow, one would have expected a serious effort by Tumolo to clarify how he intends us to understand this key concept. Unfortunately, we do not get much help in this department. If I understand Tumolo correctly, rhetoric is the art of examining how uncritically accepted patterns of thought come to take hold of people's consciousness and how new patterns of thought that deviate from these come to be accepted in their wake as legitimate or appropriate. So far so good, but it's only a start. Perhaps Tumolo does not elaborate because he intends to use the case studies in the following chapters to flesh out this definition. But there is a problem with this strategy; the case studies would have to reveal how the various terms in the definition are concretely applied. They would have to give us answers to such questions as: what constitutes the propriety or appropriateness of a particular rhetorical discourse? What factors determine whether an occasion for memorialization is opportune? The reader is left having to tease out answers to these questions from the various narratives, and while they provide some clues, there is no systematic effort to use them to provide answers.

Chapter 2 focuses on the Armenian genocide and, in particular, on the fate of a congressional resolution labeling the actions of the Ottoman Empire during World War I (WWI) as genocide.

\footnotetext{
${ }^{1}$ Michael Warren Tumolo, Just Remembering: Rhetorics of Genocide Remembrance and Sociopolitical Judgment (Madison, N.J., Fairleigh Dickinson University Press, 2015), 3.

${ }^{2}$ (Rhet. 12, 1355b26f)

${ }^{3}$ John Poulakos, “Toward a Sophistic Definition of Rhetoric," Philosophy E Rhetoric 16, no. 1 (1983): 35-48.

${ }^{4}$ Tumolo, Just Remembering, 4.
}

Jeffrey Blustein, "Book Review: Just Remembering: Rhetorics of Genocide Remembrance and Sociopolitical Judgment" Genocide Studies and Prevention 10, 3 (2016): 92-94. @2016 Genocide Studies and Prevention. 
The story here has been told before and the analysis is not novel. Tumolo argues that pragmatic political considerations having to do with the United States' use of a military base in Turkey were allowed to trump a declaration of moral principle. Forgetting the past, in this case, meant referring to the events of WWI under some other description than genocide. This is an important point that could have been expanded: one way to forget is not to advert to certain events at all; another is to advert to them, but by means of mischaracterization.

Chapter 3 reviews the story of Adolf Eichmann's capture in Argentina and his abduction to Israel to stand trial for crimes against humanity and the Jewish people. The narrative is wellconstructed, if in broad outlines quite familiar, using original material to document how the trial created a conflict between, on the one hand, international law which was violated by the abduction of Eichmann to Israel and, on the other, the moral imperative to create "a didactic moral drama" ${ }^{5}$ that would teach Jews and the world at large about the horrors of the Nazi Holocaust, then still largely unknown. The moral imperative prevailed in what Tumolo calls an analogue of jury nullification. Returning to the overarching theme of remembrance, Tumolo concludes that the trial "worked to instill a moral obligation to remember." ${ }^{\prime}$ The notion of a duty to remember is taken up again in chapter 5 .

Chapter 4 continues with the Eichmann trial, this time examining the central question to which Hannah Arendt's coverage of the trial gave rise. How should Eichmann be remembered? Was he, as Arendt argued, a thoughtless bureaucrat who merely followed orders without regard to their consequences? Or was he, as the filmmakers of a 1997 PBS documentary on Eichmann maintained, a moral monster and rabid anti-Semite? If the former, then anyone is capable of doing what Eichmann did; if the latter, then it would take a very special person, not just an ordinary human being, to do it. Tumolo draws attention to these two competing perspectives on Eichmann but too quickly, in my view, ends up favoring Arendt's interpretation. Repeating a point made in the previous chapter (there is, incidentally, considerable repetition in this book), Tumolo argues that the trial did not just serve justice by making the guilty party pay for his crimes: it also used the law to educate public opinion and inform collective remembrance. He might have noted as well that the use of law to shape collective memory through public criminal trials, so clearly evident in the Eichmann trial, is an increasingly important feature of contemporary memorial practice.

Chapter 5 continues the theme of the Jewish genocide, but this time through the lens of the President's Commission on the Holocaust. Tumolo highlights the 1979 Report of the Commission as a valuable account of the reasons for and methods of preserving memories of past atrocities. Here, if anywhere, one would expect to find the philosophical meat of the book, but the reader will be disappointed. The Report sets out to answer three questions: "1. Why Remember? 2. Whom are we to remember? 3. How are we to remember?"7 The third question is mainly reserved for chapter 6, and I will say a word about it below. As for the other two questions, Tumolo criticizes the Report's answers to both. The Jewish victims of the Nazis are not the only ones whom we are to remember, he maintains, for there have also been many other victims of bigotry and unjust discrimination, or worse. Tumolo is also dissatisfied with the Report's answer to the second question, which to me is the most philosophically interesting of the three, namely, there is a moral imperative to remember. What we need, he suggests, is a better understanding of the nature of moral imperatives than the Report provides. In his view, moral imperatives are not part of the furniture of the natural world but are human constructions, "created by human actors to help make the human lifeworld intelligible and meaningful as part of social contracts governing human relations." ${ }^{8}$ Here, unfortunately, Tumolo is quite evidently out of his depth, for each part of this sentence-human life-world, intelligible, meaningful, social contracts-virtually cries out for analysis that is not provided.

Finally, chapter 6 notes the commitment of the President's Commission to establishing

\footnotetext{
${ }^{5}$ Ibid., 34 .

${ }^{6}$ Ibid., 39 .

${ }^{7}$ Ibid., 65.

${ }^{8}$ Ibid., 67.
} 
forward-looking programs to prevent recurrence of genocide and not just to engaging in backwardlooking reflection on the wrongs of the past. Ending on a note that can hardly be contested, Tumolo maintains that "the imperative 'Never Again!' must be connected with some program of action for it to be meaningful."

Readers of this journal will find little that is new here. Accounts of the Armenian genocide and Eichmann's capture and trial, for example, do not augment what is already widely available in the literature, and this makes Just Remembering considerably less interesting than it could have been if less well known cases had been examined. Yet more disappointing, in my view, are some additional shortcomings. First is the obscurity of the definition of rhetoric, an obscurity that poses a serious problem for a book that the author claims is devoted to an analysis of the rhetoric of memorial texts. In fact, however, this claim is misleading, and this is another one of the book's problems. For while we are led to believe that an understanding of the rhetoric of memorial texts will provide new insights into the formation of collective memory, the prominence it is given in the title and the opening chapter turns out to be unwarranted. The spotlight cast on rhetoric adds little of substance to the exposition. Finally, there is the book's failure to draw general lessons about collective memory, about its "propriety" and moral value, from the case studies discussed here.

${ }^{9}$ Ibid., 88. 